\title{
Promoting Cooperation Between Corporate Social Responsibility And Inter-Organizational Relationships
}

Richard Peters, Xavier University of Louisiana, USA

Cary A. Caro, Xavier University of Louisiana, USA

\begin{abstract}
Although the fields of Corporate Social Responsibility (CSR) and Relationship Exchange have both significantly developed over the last quarter century, their content and concepts have largely remained independent. This study seeks to integrate the two streams of research by proposing an antecedent role for CSR with respect to stimulating collaborative agreements between firms and suppliers. Here we investigate the relationship between CSR and relationship exchange through a mediated model, which includes three specific factors: trust, reputation and network resources. We propose that it is through these factors that CSR influences the willingness of both partners to initiate collaborative, long-term exchanges.
\end{abstract}

Keywords: Corporate Social Responsibility; Sustainability; Antecedents for Corporate Social Responsibility; Corporate Social Responsibility Model

\section{INTRODUCTION}

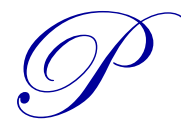

ractitioners have long realized what organizational theorists have only belatedly acknowledged: the world is a complicated, integrated place. The evolution of systems theory (Katz \& Kahn, 1978) has forced researchers in the field of organizational theory to rethink any predispositions with simplistic models that treat businesses as insular units, and acknowledge that firms, by operating in open systems, are impacted and related to individuals, groups and institutions outside the organizational boundaries. Prahalad and Hamel (1994) assert that firms are continuously forced to respond to the demands of investors, customers, communities, societies, competitors, suppliers, and governments, and that the actions and interests of these groups directly affect firm strategy, survival and inevitability sustainability. Therefore, the firm must not only manage its internal environment effectively, but also its external environment, if it is to have any plausible chance at survival, growth and profitability (Simms, 2002).

Kakabadse, Rozuel, and Davies (2005) examined the interrelatedness of CSR and stakeholder theory. Freeman (1984) proposed stakeholder theory to essentially codify the necessity of external environment management. He deemed that actors such as customers, employees, communities, stockholders, suppliers, and the general society act as firm stakeholders. In the stakeholder theory model, the relationship between the firm and its stakeholders is dyadic. The firm, through its decisions and actions, affects the welfare of its stakeholders, while simultaneously being impacted by their stakeholders' demands and activities (Evan \& Freeman, 1988). This dyadic concept is analogous to a systems approach and positions the firm as both an economic and social agent (Donaldson \& Preston, 1995).

Because Freeman's model treats the firm as an active social agent, it is conventionally conceptualized as Corporate Social Responsibility (CSR). Defining CSR is not always an easily achievable task (although many have attempted to in the past). It has evolved from being treated as a purely altruistic and moral duty entrusted to all businesses (Bowen, 1953; Davis, 1973), to a contemporary perspective positing that both business and society can instrumentally and mutually benefit from fostering effective, successful stakeholder relationships (McGuire, et al., 
1988; Berman, et al., 1999; Waddock \& Graves, 1997; Waddock, 2003). Contemporarily, CSR is viewed more as social investment, social capital creation and corporate citizenship, rather than simply moral obligation (Waddock, 2003). 'CSR firms' voluntary acknowledge the presence and demands of their stakeholders, and seek ways to develop, coordinate, and integrate interests through optimally beneficial relationships. CSR therefore becomes not only a social enterprise, but also a strategic initiative that emphasizes capitalization of relationship resources. Further, it builds value creating networks between and among the firm and its stakeholders (Hillman \& Keim, 2001).

Because of its inherent links to relationship facilitation, development and sustenance, CSR seems primed to be integrated into the economic, marketing, management, and strategic research, which concentrate on organizational and inter-organizational relationships. There has been a concerted effort to comprehensively evaluate relationships between and among firms. This includes investigating the consequences of inter-organizational relationships (Cannon \& Perreault, 1999; Kogut, 1988; Johnson \& Linton, 2000; Johnston, et al., 2004), the antecedents of these relationships (Doney, Cannon, \& Mullen, 1998; Gulati, 1999; Zaheer, McEvily \& Perrone, 1998), and the development process that firms undergo when they engage in exchange relationships (Cook, 1977; Ring \& Van de Ven, 1994).

Inter-firm relationships have evolved beyond the transaction cost economics of alternative governance structures (Williamson, 1979), to incorporate situational, cognitive, and behavioral determinants such as trust, reputation and power (Ring \& Van de Ven, 1994). Hoyt and Huq (2000) and Jap (1999) suggest that because interorganizational interactions have progressed from 'market-type' one-off transactions to collaborative, strategic initiatives, there exists a substantial need to more fully comprehend the why, how, where and what of interorganization exchange relationships.

While the term inter-organizational relationships can be used to classify numerous firm interactions (including consumers, industry members, governments, social institutions), it often refers to buyer-seller relationships between the firm and its supplier. Supplier-firm relationships directly address the 'make or buy decision' issue, and highly affect firm success, especially in volatile environments (Handfield \& Nichols, 1999; Hoyt \& Huq, 2000). If firms decide to acquire its input externally, it must engage in exchange transactions. These transactions become exchange relationships when transaction frequency increases and both parties (supplier and buyer) seek to mutually benefit from the relationship (Cook, 1997). Williamson (1979) posits that exchange relationships serve as alternatives to markets and hierarchies and can, therefore, serve to minimize transactions costs. Further, research has proposed that collaborative supplier-firm relationships can benefit the firm through improved efficiency, enhanced technology and quality, social capital facilitation, and even competitive advantages (Smeltzer, 1997; Zaheer, et al., 1998; Dyer \& Singh, 1998; Adler \& Kwon, 2002). Correspondingly, supply-chain management has received considerable attention and continues to exact distinct influence in academic and practitioner circles.

Despite this popularity, the link between CSR and supplier-firm relationship management has been relatively neglected. Murphy and Poist (2002), in calling for an increase in social responsibility logistic research, suggest that management increasingly see suppliers as stakeholders, and supply management as a socially responsible action. Therefore, ignoring the implicit and explicit ties between CSR and inter-organizational relationship research is imprudent and unjustified. While there have been previous attempts to merge these two streams (Carter \& Carter, 1998; Maignan, Hillebrand \& McAlister, 2002; Carter \& Jennings, 2004), they represent only the tip of the iceberg. Carter and Jennings (2004) note that most CSR/ supplier management research concludes that firms only consider CSR issues in choosing their suppliers. Still, this is done only if there is considerable pressure by its customers and investors to do so. We argue here that while stakeholder and societal pressures may foster the role of CSR in facilitating supplier-firm relationships, it cannot, independently, fully explain how CSR enhances supply-chain management. Instead of focusing on the social demands to institute CSR, we theorize that a CSR orientation, by both the supplier and the firm, is related to three antecedents of inter-organizational relationships: trust, reputation, and network resource accessibility. These three antecedents have been previously identified as criteria for evaluating prospective organizational partners (Doney, Cannon \& Miller, 1998; Gulati, 1999; Gulati, Nohria \& Zaheer, 2000). We therefore propose that by impacting these three factors, CSR influences the choice of both suppliers and firms with respect to establishing inter-organizational relationships. 
Because we include both the firm and its supplier in our model, we treat the inter-organizational relationship and the effect of CSR as dyadic. It is difficult to evaluate the antecedents of inter-firm relationships without considering the needs of all parties involved. Therefore, we emphasize the needs and desires of both relationship actors, although for simplicity, we treat the firm as the principle actor.

Before presenting the model and presenting theoretical development, we next discuss the previous research related to our topic.

\section{LITERATURE REVIEW}

Review of preceding literature indicates a relative paucity with respect to research in the area of CSR facilitating any inter-organizational relationships including supplier-firm links. The studies that have addressed this issue tend to identify individual dimensions of CSR such as environmental management, community involvement, and product quality as criteria for rating and choosing suppliers. For example, Maignan, Hillebrand, and McAlister (2002) prescribe that firms should incorporate suppliers' corporate social performance into their supplier decisionmaking process. They label this as socially responsible buying, somewhat analogous to social responsible investing (Verschoor, 2003). Firms are urged to choose and form partnerships with suppliers that demonstrate superior commitment to socially responsible actions. Their respective stakeholders, the authors argue, will reward the firm. They will also benefit through an enhanced firm reputation. Similarly, Handfield, Wallon, Seegers, and Melnyk (1997) and Min and Galle (1997) assert that concern for the natural environment on the part of suppliers can be attractive to potential firm buyers who undertake environmental supply management. Along with environmental management, Emmelhainz and Adams (1999) posit that employee relations/labor conditions are another CSR dimension that firms use to evaluate suppliers. Employee relations, especially when they are poor, are often treated as social issues, which transcend organizational boundaries. Therefore firms, fearful of a 'guilty by association' backlash, may wish to only align themselves with suppliers who provide adequate labor conditions and demonstrate concern for employee well-being.

While acknowledging that these CSR dimensions individually can be used to assess suppliers from a social responsibility perspective, Carter and Jennings (2004) advocate an aggregate approach to CSR supplier management. This aggregate approach (termed Purchasing Social Responsibility [PSR]) entails using multiple CSR criteria to evaluate suppliers. They argue that using multiple criteria allows the firm to holistically gauge the CSR intentions and the position of its potential suppliers. Therefore, the firm becomes more informed with respect to its supplier's precedent behavior and is essentially more willing to transact and form exchange relationships.

Beyond the individual facets of PSR, Carter and Jennings (2004) also identify certain 'drivers', which they propose to increase the likelihood that the firm and its management will implement a PSR policy. These drivers include: organizational culture, top management support, consumer demands, individual values and predispositions, and governmental regulations. They find empirical evidence which suggests that customer pressure, organizational culture, and management support all facilitate PSR. They also conclude that governmental regulations do not promote the proclivity of firms to collaborate with socially responsible suppliers. These results suggest that firms that are voluntarily committed to CSR (through organizational culture and commitment) are more likely to seek out relationships with like-minded suppliers, as opposed to firms, which are forced to by law.

Firms and suppliers can choose to willfully practice CSR or they can be legally mandated to do so. It stands to reason, however, that firms will be more willing to establish relationships with other firms who practice voluntary CSR. Donaldson and Preston (1995) argue that firms who demonstrate superior CSR, beyond the legal requirements of society, benefit the most from CSR. Similarly, Preston and Donaldson (1999) and Jones (1995) suggest that a decided commitment by the firm to the tenets of CSR and stakeholder management produces organizational wealth. Congruently, we posit that the effect of CSR in facilitating relationships and attracting firms to suppliers may be indirect. We propose that it is not so much the actual CSR actions of an organization, but the message that a voluntary commitment to those actions communicates to others, that creates superior rewards for the organization. Therefore, firms and suppliers may look not only at each other's CSR behaviors, but also at the commitment and consistency of these behaviors when deciding upon relationship partners. Thus, the relationship between CSR and firm-supplier relationship, we present, is mediated by the effect a commitment to CSR have on each party's ability 
to trust the other, the enhancement of public image and sustainable reputation, and whether the partnership might have accompanying network-related rewards. Gulati (1999) suggest that these three factors are often used when selecting network partners. This paper seeks to ascertain if and how a dedicated commitment to CSR contributes to these three, and in turn promotes firm-supplier relationships.

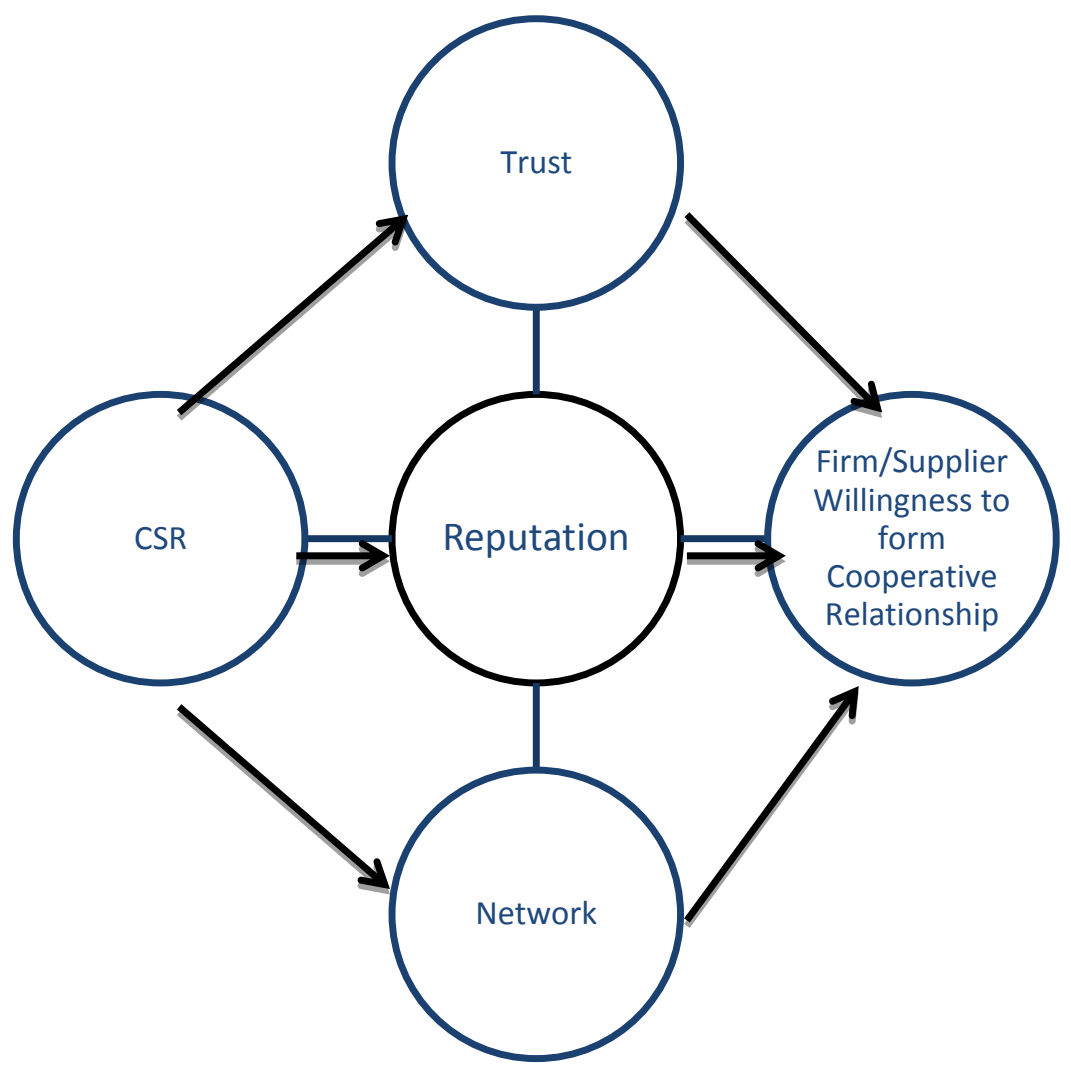

\section{THE MODEL}

CSR commitment has previously been linked to firm morality and altruism (Gibson, 2000), whereby a firm could only demonstrate a commitment to CSR if it was willing to sacrifice its self-interest for the common good (Jones \& Wick, 1999; Jones, 1995). There are, however, two problems with this treatment. First, it relies on assessing firm intentions, which is not easily achieved and often quite impractical to operationalize. Azjen and Fishbein (1980) note that individuals attribute intentions to behavior when it is difficult or unfeasible to assess underlying motivators. Outsiders are generally not privy to the rationale behind firm policies; therefore, they must often presume intentions from actions. Thus, measuring commitment from intentions in this scenario seems rather complicated and somewhat unrealistic. Secondly, it is difficult to assess whether a firm, or anyone, will participate in self-sacrifice a priori. While a firm might state or imply that it is willing to suffer a financial loss for the benefit of general society, there is no way (except through fervent trust) to test if this commitment is genuine until the firm actually and willfully suffers a loss.

Therefore, while we agree with Amato and Amato (2002) that mission statements that make mention of CSR may serve as a signal of CSR commitment, we contend that the proof of this commitment is essentially in the doing, and not in the stated intention. Firms that perpetually and voluntarily exhibit effective corporate social performance are the ones who demonstrate a commitment to their stakeholder relationships (Hillman \& Keim, 2002). Consistency in social performance indicates to outsiders that firms are investing in their stakeholder relationships, and are committed to the welfare of these relationships. 


\section{Theoretical and Hypothetical Development}

Trust

Trust plays a vital role in the health of any organization (Fulmer \& Gelfand, 2012). Of all of the cognitive/behavioral constructs included in the inter-organizational relationships research, the construct of trust has emerged as a central tenet to the initiation and development of collaborative inter-firm efforts. Doney and Cannon (1997) state that the growing volatility and competitive nature of present business environments demand that firms and suppliers build substantial value-laden relationships, and that trust facilitates the development of these joint initiatives (Morgan \& Hut, 1994). Johnson, McCutcheon, Stuart and Hazelwood (2004) similarly note that the ability of partners to mutually trust each other is a critical element for effective supply-chain management. Trust between organizations can be mediated by: shared principles among organizational members (D'Iribarne, 2003); the integrity of an organization (Palanski \& Yammarino, 2009); a shared pilot project (McCarter, Mahoney, and Northcraft, 2011); a shared network (Gluckler \& Armbruster, 2003); effective, two-way communication (Gainey \& Klaas, 2003); and, shared competition and associated risks (Croonen, 2010). Consumerism is also impacted by the perception of the product and the organization. Choi, Eldomiaty, and Kim (2007) suggest that the less familiar a consumer is with an organization's product, the less trusting the consumer will be.

Although trust is often conceptualized and treated as a psychological individual state (Lindskold, 1978; Ring \& Van de Ven, 1994), economists treat it as a governance mechanism that can reduce transaction costs (Pfeffer \& Salancik, 1978; Williamson \& Ouchi, 1981; Dasgupta, 1988). Williamson (1979) posits that as buyer-seller transactions progress from impersonal interactions to hybrid relationship structures, there is less reliance on formal contracting. Teece (1992) further suggests that because contracting in relationships is inherently incomplete, relationship participants must use governance mechanisms to reduce the level of transaction costs. Pfeffer and Salancik (1978) identify trust as a mechanism that can reduce the proclivity of opportunism, and the uncertainty of asset specificity, thereby improving the performance of the transacting parties. In transaction cost theory (TCT), trust is treated as a rational expectation of the behavior of others, rather than a purely cognitive belief. For instance, Williamson (1991) proposes that no rational party will consent to a relationship unless it believes that is not profitable for the other party to renege on the agreement. Therefore, trust, from the economic perspective, is relatively impersonal and somewhat self-serving.

While TCT does offer a direct link between trust and firm performance in hybrid relationships, it does not explicitly consider the relationship between trust and relationship development. Hoyt and Huq (2000) imply that because supplier-firm relationships now emphasize collaboration and integration, trust is seen as more than a governance mechanism. The majority of contemporary research on inter-organizational trust reflects this transition (Ellram, 1995; Doney \& Cannon, 1997; Ring \& Van de Ven, 1994; Dyer \& Chu, 2003), and promotes the role of trust as a facilitator of inter-firm collaboration, rather than merely a means to reduce opportunism. This preoccupation with trust and inter-organizational collaboration is driven by the substantial body of research tying supplier-firm cooperation to performance rewards such as innovation, efficiency, and quality (Johnson et al., 2004).

Despite the differences in definition and treatment, both the TCT and collaborative perspectives are complementary and useful paradigms for understanding the role of trust in supplier-firm relationships. Johnston, McCutcheon, Stuart, and Kerwood (2004) suggest that most conceptualizations include two facets: dependability (predictability) and benevolence. Dependability refers to the consistency and reliability of words and past behavior. It is highly congruent with the TCT's emphasis on reducing uncertainty in contracting. Benevolence, on the other hand, is related to the perception that the transacting partner is generally concerned for the well-being of others and interested in generating mutual benefits (Smeltzer, 1997; Doney \& Cannon, 1997). Benevolence is, therefore, indicative of the collaborative perspective. It also incorporates some elements of TCT, especially with respect to opportunism.

Doney \& Cannon (1997) posit that individuals and organizations will attempt to gather information on both benevolence and dependability before making a trust decision. They look at previous attitudes and behaviors to determine the level of credibility, honesty, and commitment potential and existing partners have portrayed. Therefore, organizations look for signals and information from which to gauge intentions, and use these signals as proxies for dependability, credibility, and benevolence (Kumar, Scheer \& Steenkamp, 1995). 
CSR actions are often visible and relatively explicit (Fombrun \& Shanley, 1990). As such, they can act as a key source of information about both dependability and benevolence. With respect to dependability, suppliers and firms can examine the frequency and consistency of CSR behavior to help assess credibility. In so much that CSR actions are directed towards multiple stakeholders, outsiders are also privy to whether the organization credibly and voluntarily honors its promises and obligations to its relationship partners in various settings and contexts.

Because in this study we propose that trust acts an antecedent to relationship formation, the potential relationship participants assumedly cannot rely on direct experiences to judge dependability (Doney \& Cannon, 1997). Therefore, both parties (suppliers and firms) must use secondary information to ascertain whether their potential partner is predictable, consistent, and credible. This is analogous to the trust transference process, whereby organizations use the experiences and evaluations of others to determine (albeit indirectly) the trustworthiness of another organization (Ganesan, 1994). Ganesan (1994) further notes that the level of trust is heightened when multiple third party 'proof sources' exist (i.e. one is more willing to trust the advice of many, as opposed to few). Therefore, we argue that the organization will be more confident in its assessment of potential partner predictability when there is extensive verifiable information about past behaviors and when this information is provided by multiple, trustworthy sources. Because CSR incorporates multiple dimensions and multiple stakeholders, it fulfills these two criteria (extensive information and multiple proof sources).

H 1(a): Firms will view suppliers that demonstrate a commitment to CSR as being highly dependable H 1(b): Suppliers will view firms that demonstrate a commitment to CSR as being highly dependable

Johnston et al., (2004) posit that for trust to exist, the trustee must not only perceive the trusted to be dependable, but they must also view them as benevolent. Benevolence is conceptualized as goodwill (Johnson et al., 2004), consideration for the welfare of others (Doney \& Cannon, 1997), and as ethical behavior (Smeltzer, 1997). It is implicitly linked to a long-term orientation (Ganesan, 1993), where both the firm and the supplier seek to not only consistently meet their contractual obligations (Zaheer et al., 1998), but also to develop the exchange relationship over an extended time period.

Ganesan (1994) proposes that benevolence constitutes a willingness to acknowledge and protect the interest of others, even when one is not legally mandated to do so. Again, we refer to the difference between voluntary regulative (stipulated by law) CSR behavior (Caroll, 1979). While CSR behavior, irrespective of its underlying motives, might communicate dependability, only voluntary CSR can reflect benevolence. Since dependability is concerned with credibility and the likelihood that organizations will live up to pre-established obligations, it is not overly concerned with organizational intentions (Doney \& Cannon, 1997; Zaheer et al., 1998). However, to assess the level of benevolence, organizations must question motives and determine whether organizational partners, or potential partners, are genuinely interested in their distinct welfare. A voluntary commitment to CSR presumes an acknowledgement of multiple stakeholder obligations, and a concerted decision by the organization to fulfill these obligations through effective stakeholder relationship management (Donaldson \& Preston, 1995; Berman et al., 1999). Because the organization is under no mandatory duress to act in a socially responsible manner, its decision clearly reflects a concern by the organization and its management for the well-being of its stakeholders.

CSR commitment also demonstrates willingness by the organization to strategically foster and develop its stakeholder relationships (Berman et al., 1999). The organization attempts, through CSR, to create and sustain value-added relationships that mutually benefit the organization and its stakeholder partners. Congruently, Doney and Cannon (1997) view benevolence as a commitment to cooperation and joint rewards. We posit that the firm's ability to sustain its stakeholder relationship (demonstrated by longitudinal CSR consistency) demonstrates a desire to promote and achieve mutually beneficial outcomes.

H 2(a): Firms will view suppliers that demonstrate a commitment to CSR as being highly benevolent H 2(b): Suppliers will view firms that demonstrate a commitment to CSR as being highly benevolent 


\section{Reputation}

\section{$\underline{\text { Indirect Effect }}$}

Fombrun, Gardberg, and Barnett (2000) suggest that CSR is a direct strategic device to manage reputational risk. Lewis (2003) also deems CSR as a fundamental concern for stakeholders and stockholders with respect to the evaluation of firm image and performance. The intrinsic bond between CSR and firm reputation is even more evident considering that reputational indices have been used and continue to be incorporated in the conceptualization and measurement of corporate social performance (Waddock \& Graves, 1997).

Reputation and public image is discussed with respect to inter-organizational relationships. Supplier reputation has previously been presented as a direct antecedent to trust (Doney \& Cannon 1997; Ganesan 1994; Smeltzer 1997); the conventional wisdom proposing that firms are more likely to trust suppliers that are reputable. Doney and Cannon (1997) define reputation as the "extent to which firms and people in the industry believe a supplier is honest and concerned about its customers" (pg. 351). This definition, therefore, relates the concept of trust to the aspect of benevolence, implying that an organization's reputation is a critical source of information about a potential partner's willingness to serve the interest of others. Smeltzer (1997) notes that trust is based on external perceptions of organizational image and identity, wherein individuals and organizations assess the concerns for others in society, based on reputation, before determining whether the organization can and should be trusted.

Both these treatments of trust make mention of social concern. Reputation goes beyond dependability to incorporate social desirability and corporate social performance (Fombrun, 1996). An organization's public image and reputation is constructed on consistent behavior, and on demonstrations of social investment and goodwill (e.g. community involvement, philanthropy, environmental preservation). Since organizational reputation and public image are socially created phenomena derived from perceptions (Ganesan, 1994), the more socially desirable an organization is perceived to be, the more favorable is its public image and reputation. Effective and voluntary CSR behavior enhances public image and firm reputation by directly influencing these public perceptions (Fombrun \& Shanley, 1990; Fombrun, Gardberg \& Barnett, 2000). Organizations that willingly implement CSR are viewed as socially aware and committed to serving the interests of multiple members of society. This leads to distinct reputational rewards through increased investment (Verschoor, 2003) and reduced risk ratings (Orlitzsky \& Benjamin, 2001), both indications of enhanced trustworthiness.

Reputation is also centrically tied to corporate identity and organizational values (Dutton \& Dukerich, 1991; Smeltzer, 1997), and it indicates to outsiders what the organization truly believes in and practices. Therefore, organizational reputation, based on CSR, is not a consequence of public image enhancement; rather, it is a result of demonstrated consistency in corporate social performance, which we treat as a commitment to CSR. It is this commitment that fuels trust which leads to supplier-firm relationship formation.

H 3(a): Firms are more likely to trust suppliers with enhanced CSR reputations

H 3(b): Suppliers are more likely to trust firms with enhanced CSR reputations

\section{Direct Effect}

While the reputational effects of CSR commitment can indirectly affect supplier-firm relationship formation, CSR-based reputation can also play a more direct role in facilitating relationship initiation. Podolny (1993) suggests that organizational status or reputation is somewhat dependent on the reputation of others, to which the focal organization is linked. This is demonstrated in the link between organizations and their spokespersons, and between firms and their suppliers. Companies are quick to terminate links with spokespersons and suppliers if their images and reputations become tarnished, hoping to avoid a similar fate (guilty by association).

However, this 'transference of reputation' effect can also work advantageously. In an effort to enhance firm image, companies usually choose spokespersons that are popular, socially desirable, and reputable. Similarly, firms and suppliers consider the effect that their potential partner's reputation will have on their own reputation. Orlitzsky and Benjamin (2001) suggest that a positive CSR reputation increases the willingness for affiliation. Because society 
places added value on stakeholder management (Prahalad and Hamel, 1994) and corporate social performance (Simms, 2002), it is logical to expect members of society to have a greater affinity for organizations that demonstrate a high level of corporate social responsibility. It should also be expected that other organizations will seek out relationships with such institutions.

Since reputations are also a function of organizational identity, it may also provide information about organizational policies and values (Smeltzer, 1997). Social Identity Theory (Dutton \& Dukerich, 1991) proposes that individuals attempt to determine whether the organization's values and interests are congruent with personal attitudes and values. Analogously, Doney, and Cannon (1997) posit that firms try to discern whether the interests and values of its suppliers are similar to those of their own before determining if and how the relationship should develop. By using organizational reputation, both suppliers and firms can learn and communicate their respective corporate identities, cultures, and values. Therefore, there is an opportunity for pre-evaluation of value congruency that can help in the relationship-formation decision process.

H 3(c): Firms will be more likely to form relationships with suppliers that have positive CSR reputations H 3(d): Suppliers will be more likely to form relationships with firms that have positive CSR reputations

\section{Networks and Network Resources}

Thus far we have treated the single, dyadic relationship as the unit of analysis. We now extend our discussion to acknowledge that the firm, and its potential supplier, can possibly be embedded in distinct or convergent networks (Gulati, 1995; Gnyawali \& Madhavan, 2003). These networks include social, strategic, and exchange relationships that bind multiple actors together (Gulati, Nohria \& Zaheer, 2000). Gulati (1999) and Chung, Singh, and Lee (2000) assert that networks, by virtue of their ability to incorporate multiple actors and relationship types, can provide idiosyncratic and valuable resources to their members. Gulati, Nohria, and Zaheer (2000) label these as 'network resources', and argue that because these resources may be valuable, rare, and difficult to copy (Barney, 1991), they are a potential source of competitive advantage. Gulati (1999) further suggests that these network resources are not intra-organizationally derived, but reside implicitly within the network structure and the specific inter-organizational relationships embedded within these structures. Essentially, then, organizations can only access these resources through direct and/or indirect network membership.

\section{Information}

Gulati (1995 \& 1999), Chung, Singh, and Lee (2000) and Walker, Kogut, and Shan (1997) posit that organizations can gain entry to networks and their associated resources through alliance formation. By forming alliances, organizations can mutually and complementarily benefit from each other's respective networks and increase their resource accessibility exponentially. Gulati (1999) proposes that organizations will seek out alliance partners that can provide access to network resources, which are then valuable to the organization.

One such resource is information. Because networks embody a variety of interlocking links across various institutions, groups, and individuals, they often offer rich sources of information transmitted over multiple information channels (Powell, 1990; Gulati \& Westphal, 1999). In an era where access to timely, valuable information is critical to firm success, the ability of a network to facilitate communication, and thereby diffuse information across organizational and institutional boundaries, can often grant its members distinct advantages and rewards.

Because we treat CSR here as the coordination and fulfillment of multiple stakeholder interests (Evan \& Freeman, 1998; Donaldson \& Preston, 1995), it is logical to conceptualize these multiple stakeholder relationships as a distinct network. This network includes social and environmental ties (e.g. community involvement, environmental management) and exchange relationships (e.g. suppliers, distributors, consumers, strategic partners). The organization, through building and sustaining meaningful relationships with these separate stakeholder groups, acquires information from relevant and distinct sources, which it can specifically use to formulate strategy and to enhance performance (Berman et al,. 1999). Hillman and Keim (2001) propose that the more extensive the stakeholder network is (i.e. the more stakeholder relationships the firm creates), the greater the performance rewards 
and opportunity for competitive advantages. Also, the informational benefits derived from stakeholder relationships progressively increase along relationship tenure because of the presence of increased trust and reciprocity (Preston \& Donaldson, 1999; Orlitzsky \& Benjamin, 2001). Therefore, the network informational resources are expected to be most prolific in instances where the organization engages in multiple stakeholder relationships and where it demonstrates a voluntary commitment to CSR.

Being that CSR creates distinct stakeholder networks with unique informational advantages, and assuming that organizations outside of this network desire access to this resource, the following is proposed:

H 4(a): Firms will seek to form relationships with suppliers committed to CSR because they offer access to unique network information

H 4(b): Suppliers will seek to form relationships with firms committed to CSR because they offer access to unique network information

\section{Social Capital}

Along with information, organizations can also derive social capital from its position and connections in the network structure. Social capital has been adopted by strategic researchers to describe the intangible rewards organizations derive from their relationships with networks. Adler and Kwon (2002) define it as "engendered goodwill from social relations" (pg. 297), treating social capital as the potential for future benefits from present network memberships (Portes, 1998). Organizations that invest in and sustain effective relational ties with its network affiliates (either through social links or exchange relationships) are likely to reap substantial rewards over an extended period of time (Kostova \& Roth, 2003). In this respect, social capital is analogous to technological and financial investment, wherein the organization attempts to leverage a current resource (social capital), to produce sustainable future pay-offs. These future benefits include increased resource accessibility (Walker, Kogut \& Shan, 1997; Chung et al., 2000), enhanced efficiency and cost reductions, (Baker, 1994) and cooperative synergy (Burt, 1992).

Similar to information, Gulati (1999) and Chung et al., (2002) treat social capital as inter-organizational phenomena, embedded in the organization's network relationships. As a distinct network resource, social capital provides network members with unique, valuable advantages that are inaccessible to outsiders (Gulati \& Garguilo, 1999). At the individual level, Kostova and Roth (2002) posit that firms create and access social capital by using 'boundary spanners', employees who form relationships with individual members of other organizations. This is congruent to alliance formation at the organizational level, wherein organizations establish relationships with other institutions and groups in order to extend its social capital base and facilitate new social capital development (Adler \& Kwon, 2002). The organization, then, benefits when this form of social capital is applied to the system, whereby it promotes organizational learning and progress (Caro, 2011).

Because CSR fosters economic, social, and moral ties between business and stakeholder groups (Davis, 1973), it is complementary to the concept of social capital. As organizations promote positive interactions with their stakeholders, there is, arguably, the development of trust and greater proclivity for reciprocity through goodwill (Adler, 2001). Voluntary commitment to CSR, through preservation of stakeholder relationships, helps a firm maintain its network and accumulate social capital. This social capital, in turn, produces both intangible and tangible performance-related benefits, which Preston and Donaldson (1999) term 'organizational wealth'.

Therefore we posit that firms that are committed to CSR will accumulate substantial social capital and therefore be prime targets for partnerships and alliances.

H 4(c): Firms will seek to form relationships with suppliers committed to CSR because they offer access to social capital

H 4(d): Suppliers will seek to form relationships with firms committed to CSR because they offer access to social capital 


\section{DISCUSSION}

Environmental uncertainty is, ironically, the only constant that business organizations operating in a complex world can assuredly depend on. The unenviable task for management has always been to plan and implement strategy that aligns the goals of the organization with the demands of a perpetually changing environment. Faced with this challenge, organizations are turning increasingly to inter-firm relationships to provide some measure of stability and predictability (Hoyt \& Huq, 2000). By creating strategic alliances and cooperative relationships, organizations gain relatively more control over transactions, thereby eroding the effect of market uncertainty on business exchanges (Williamson, $1979 \& 1991$ ). The advantages these alliances might confer to participating organizations, however, go beyond providing environmental certainty and minimizing transactions costs, to also include increased resource accessibility, enhanced technological innovation, and improved firm effectiveness. While there is a growing body of evidence supporting the theory that strategic alliances promote organizational performance, it is premised on the contingency that performance is largely determined by choosing the 'right' alliance partner (Hagerdoon, 1993). Thus, researchers have spent considerable time investigating the antecedents of alliance formation and attempting to prescribe criteria on which to evaluate the suitability of potential exchange partners.

We contribute to this growing body of research by positioning Corporate Social Responsibility as a possible antecedent to supplier-firm relationship formation. CSR has traditionally been conceptualized as an ethical issue; however, it has recently been transformed into a strategic endeavor with consequential performance rewards for organizations willing and capable of implementing social responsibility initiatives (Waddock \& Graves, 1997; Berman, et al., 1999). Researchers are now seeking to integrate CSR with other strategic concepts, attempting to demonstrate how and why socially responsible behavior fits into the framework of business organizations. However, the relationship between CSR and supplier-firm relationships has largely been ignored, leaving substantial opportunities for discussion. Previous studies that have tackled this issue have concentrated almost exclusively on the dimensions of CSR and how they relate to purchasing decisions on the part of the firm. Therefore, there is little exploration of the role of CSR in facilitating exchanges, and even less investigation about its possible links to supplier-firm partnership formation and development.

While we acknowledge that firms can, and should, use the dimensions of CSR to evaluate prospective suppliers, we propose that the usefulness of CSR to firm-supplier exchanges goes well beyond this relationship. Beyond assisting firms in choosing suppliers for one-off market transactions, we argue here that CSR can promote collaborative inter-organizational relationships between two organizational actors (firms and suppliers) by increasing organizational attractiveness through distinct factors.

The first of these factors is trust, dissected into the facets of dependability and benevolence. For this factor, dependability is concerned with credibility and consistency of action, and benevolence is related to concern for the welfare of others. CSR is related to both facets in that it facilitates multiple stakeholder relationships, which leads to the fulfillment of multiple stakeholder interests. We argue that a voluntary commitment to CSR indicates a willingness by the organization to first acknowledge and then protect the interest of others in society. Also, by sustaining consistency with respect to social performance, the organization demonstrates dependability and thus enhances its trustworthiness in the perceptions of potential relationship partners.

Because organizational pre-partnership cannot necessarily assess potential partner trustworthiness from direct previous experience, they must rely on credible secondary information. Organizational reputation provides an avenue for organizations to evaluate how an organization is publicly perceived and provides information about its previous relationship behaviors. A reputation predicated on the dimensions of CSR offers an opportunity for organizations to gauge the dependability and benevolence of their prospective partners from multiple sources and contexts (e.g. employees, communities, suppliers), potentially increasing confidence, trustworthiness, and a willingness to form a collaborative partnership.

Organizations with positive CSR reputations are often perceived as socially desirable. This enhanced social desirability, we argue, promotes organizational attractiveness and thereby increases the willingness of others to affiliate themselves in a meaningful way with the organization. 
Lastly, we recognize the firm and its supplier(s) as actors in distinct, idiosyncratic networks. Each organization, by virtue of its existing relationships, is a member of a unique network structure that can provide substantial network resources. Two such resources are information and social capital. Information helps the organization in its decision-making, planning, and strategizing and because networks incorporate multiple institutions and organizations, they offer a variety of information channels through which the organization can transmit and receive valuable and timely information. Social capital, on the other hand, facilitates interorganizational cooperation and improved future performance by engendering goodwill and reciprocity among network members. Organizations that practice CSR create networks with stakeholder groups. These stakeholder networks can be extensive and valuable since they contain social, economic, and strategic ties that increase information accessibility and generate social goodwill. To assess these resources and attain the benefits that they provide, organizations seek to form alliances and relationships. Therefore, by fostering unique stakeholder networks and engendering valuable network resources, CSR also contributes to the organization's attractiveness as a potential relationship partner.

\section{CONCLUSION \& IMPLICATIONS FOR FUTURE RESEARCH}

This paper is an attempt to build on the conceptual and empirical foundations of a multitude of previous work. It integrates two streams of study, inter-organizational relationships and CSR, in order to demonstrate the possible role that CSR can play in bringing suppliers and firms together.

By developing arguments relating CSR to trust, reputation, and network resources, we have presented a conceptual framework that links socially responsible activity with the ingredients for effective partnership initiation, coordination, and growth. However, the emphasis on these three variables should not be construed as a belief by the authors that the model is complete. We concede that there may exist other mediators such as firm performance, which might help improve the efficacy of the model and promote learning in the field. This we deem as an area where future efforts could be directed.

Also our model does not explicitly consider the effect of moderating variables. For instance, Cook (1977) and Ganesan (1993) propose that power may influence the willingness of parties to enter into exchange relationships. Because it is assumed here that the firm and the supplier are equivalent with respect to power distribution, the discussion and propositions do not make concessions for power inequalities. We admit that this is somewhat unrealistic and a research limitation; however, it provides an opportunity for future investigation and the possibility of enriching and expanding the model.

While we acknowledge our limitations, we deem the model to be an adequate framework for future development. We agree with Carter \& Jennings (2004) that more research is needed with respect to CSR and supplier-firm interactions. Both these topics are academically worthwhile and socially relevant. Therefore it is our hope, that aside from making a valuable contribution to the field, this paper serves as a catalyst for similar future endeavors.

\section{AUTHOR INFORMATION}

Dr. Richard Peters is an Assistant Professor of Management at Xavier University of Louisiana. He currently teaches at the Undergraduate level in the Division of Business. His research interests are in Corporate Social Responsibility and Sustainability (CSRS) and International CSRS Pedagogy, with a recent emphasis on emerging markets. He has published articles in the International Journal of Management and Enterprise Development and Journal of Management and Organization (forthcoming) and has presented at numerous national and regional conferences. Richard Peters, Ph.D., Xavier University of Louisiana, USA. E-mail: rpeters1@xula.edu

Dr. Cary Caro is an Assistant Professor of Management at Xavier University of Louisiana, where he teaches at the undergraduate level in the Division of Business. His research interests include Sports Economics, Human Resource Development, Sustainability, and Corporate Social Behavior. He has published in the International Journal of Sports Science and Coaching and the American Journal of Criminal Justice. He currently serves at Managing Editor for the American Journal of Business Education. Cary A. Caro, Ph.D., Xavier University of Louisiana, USA. E-mail: ccaro@xula.edu (Corresponding Author) 


\section{REFERENCES}

1. Adler, P.S. and S.W. Kwon. 2002. "Social capital: Prospects for a new concept." Academy of Management Review. 28: 204-219.

2. Adler, P.S. (2001). "Market, hierarchy, and trust: the knowledge economy and future of capitalism." Organization Science, 12: 215-234.

3. Azjen, I., and M. Fishbein 1980. Understanding attitudes and predicting social behavior. Prentice Hall, Upper-Saddle River.

4. $\quad$ Baker, W.E. (1994). Networking Smart: How to Build Relationships for Personal and Organizational Success, McGraw-Hill, NY.

5. Berman, S.L., Wicks, A.C., Kotha, S and Jones, T.M. (1999). "Does stakeholder orientation matter? The relationship between stakeholder management models and firm financial performance." Academy of Management Journal, 42, 488-506.

6. Bowen, Howard. (1953). Social Responsibilities of the Businessman. New York: Harper.

7. Burt, R.S. (1992). Structural Holes. Harvard University Press, Cambridge, MA.

8. Cannon, Joseph P. and William D. Perreault, Jr. (1999), "The Nature of Buyer-Seller Relationships in Business Markets," Journal of Marketing Research, 439-460.

9. Caro, C. A. (2011). "Predicting State Police Officer Performance in the Field Training Officer Program: What Can We Learn from the Cadet's Performance in the Training Academy? " American Journal of Criminal Justice, 36(4), 357-370.

10. Carroll, A. B. (1979), "A Three-Dimensional Conceptual Model of Corporate Social Performance," Academy of Management Review, 4(4), 497-505.

11. Carter, C.R. and M.M. Jennings (2004). "The role of purchasing in corporate social responsible: a structural equation analysis." Journal of Business Logistics, 25(1), 145-187.

12. Carter, C. R. and J. R. Carter (1998), "Interorganizational Determinants of Environmental Purchasing: Initial Evidence from the Consumer Products Industries," Decision Sciences, 29(3), 659-685.

13. Choi, C., Eldomiaty, T., \& Kim, S. (2007). "Consumer trust, social marketing and ethics of welfare exchange." Journal of Business Ethics, 74: 17-23.

14. Chung, S., Singh, H. and K. Lee (2000). "Complimentary, status similarity and social capital as drivers of alliance formation.” Strategic Management Journal, 21: 1-22.

15. Cook, K.S. (1977). "Exchange and Power in networks of interorganizational relations." The Sociological Quarterly, 18: 62-82.

16. Croonen, E. (2010). "Trust and fairness during strategic change processes in franchise systems." Journal of Business Ethics, 95: 191-209.

17. Dasgupta, P. (1988), Trust as a Commodity," in Trust: Making and Breaking Cooperative Relations, Diego Gambetta, ed. New York: Basil Blackwell, Inc.

18. Davis, K (1973). "The case for and against business assumption of social responsibilities." Academy of Management Journal, 16, 312-322.

19. D'Iribarne, P. (2003). "The combination of strategic games and moral community in the functioning of firms." Organization Studies, 24, 1283-1307.

20. Donaldson, T., Preston, L.E. (1995). "The stakeholder theory of the corporation: concepts, evidence, and implications." Academy of Management Review, 20, 65-91.

21. Doney, Patricia M., J. P. Cannon, and M. Mullen (1998) "Understanding the Influence of National Culture on the Development of Trust," Academy of Management Review, 601-620.

22. Dutton, J. E., and Dukerich, J. M. (1991). "Keeping an eye on the mirror: Image and identity in organizational adaptation." Academy of Management Journal, 34, 517-554.

23. Dyer, J.H. and W. Chu (2003). "The role of trustworthiness in reducing transaction costs and improving performance: Empirical evidence from the United States, Japan, and Korea." Organization Science, 14(1), 57-69.

24. Ellram, L. M. (1995). "A managerial guideline for the development and implementation of purchasing partnerships." Journal of Supply Chain Management, 31(2), 9-16.

25. Emmelhainz, M. A. and R. J. Adams (1999), "The Apparel Industry Response to 'Sweatshop' Concerns: A Review and Analysis of Codes of Conduct," Journal of Supply Chain Management, Vol. 35, No. 3, pp. 5157. 
26. Evan, W.M., \& Freeman, R.E. (1988). "A stakeholder theory of the modern corporation: Kantian capitalism.” In T. Beauchamp \& N. Bowie (eds.), Ethical theory and business: 75-93. Englewood Cliffs, NJ: Prentice Hall.

27. Fombrun, C. (1996). Reputation: Realizing value from the corporate image. Boston: Harvard Business School Press.

28. Fombrun, C., \& Shanley, M. (1990). "What's in a name? Reputation building and corporate strategy." Academy of Management Journal, 33, 233-258.

29. Fombrun, C., Gardberg, N. and Barnett, M. (2000) "Opportunity platforms and safety nets: Corporate citizenship and reputational risk”, Business and Society Review, 105(1), 85-106.

30. Frankental, P. (2001). Corporate social responsibility-a PR invention?. Corporate Communications: An International Journal, 6(1), 18-23.

31. Freeman, R.E. (1984). Strategic management: A stakeholder approach. Boston: Pitman

32. Fulmer, C. A., \& Gelfand, M. J. (2012). "At What Level (and in Whom) We Trust Trust Across Multiple Organizational Levels". Journal of Management, 38(4), 1167-1230.

33. Gainey, T. W., \& Klaas, B. S. (2003). "The outsourcing of training and development: Factors impacting client satisfaction.” Journal of Management, 29: 207-229.

34. Ganesan, S. (1993). "Negotiation Strategies and the nature of channel relationships." Journal of Marketing Research, 30, 183-203.

35. Ganesan, S. (1994), "Determinants of Long-Term Orientation in Buyer-Seller Relationships," Journal of Marketing, 58:1-19.

36. Gibson, K (2000). "The moral basis of stakeholder theory." Journal of Business Ethics. 26(3): $245-257$.

37. Glückler, J., \& Armbrüster, T. (2003). "Bridging uncertainty in management consulting: The mechanisms of trust and networked reputation.” Organization Studies, 24: 269-297.

38. Gnyawali, D.R. and R. Madhavan. 2001. "Cooperative networks and competitive dynamics: a structural embeddedness perspective." Academy of Management Review. 26: 431-445.

39. Gulati, R., \& Westphal, J. (1999). "The dark side of embeddedness: An examination of the influence of direct and indirect board interlocks and CEO/board relationships on interfirm alliances." Administrative Science Quarterly, 44, 473-506.

40. Gulati, R. (1999). "Network location and learning: The influence of network resources and firm capabilities on alliance formation." Strategic Management Journal, 20: 397-420.

41. Gulati, R., Nohria, N., \& A. Zaheer (2000). "Strategic Networks." Strategic Management Journal, 21: 203215.

42. Hagerdoon, J. (1993). "Understanding the rationale of strategic technology partnering: Inter-organizational modes of cooperation and sectoral differences." Strategic Management Journal, 14, 5: 371-386.

43. Handfield, R.B. and Nichols, E.L. (1999). Introduction to Supply Chain Management, Prentice-Hall, NJ.

44. Handfield, Robert B., S.V. Wallon, L. K. Seegers, and S. A. Melnyk (1997). "Green Value Chain Practices in the Furniture Industry," Journal of Operations Management, Vol. 15, No. 3, pp. 293-315.

45. Hillman, A and G.D. Keim (2001). "Shareholder value, stakeholder management and social issues: What's the bottom line?" Strategic Management Journal, 22(2), 125.

46. Hoyt, J. \& F. Huq (2000). "From arms-length to collaborative relationships in the supply chain: An evolutionary process” International Journal of Physical Distribution \& Logistics Management, 30(9), 750.

47. Johnston, D.A., D.M. McCutcheon, F.I. Stuart \& H. Kerwood (2004). "Corrigendum to Effects of supplier trust on performance of cooperative supplier relationships" Journal of Operations Management, 22(5), 525.

48. Jones, T.M. (1995). "Instrumental Stakeholder Theory: A synthesis of ethics and economics." Academy of Management Review, 20, 404-437.

49. Jones, T.M. and Wicks, A.C. (1999). "Convergent Stakeholder Theory." Academy of Management Review, 24, 191-221.

50. Kakabadse, N. K., Rozuel, C., \& Lee-Davies, L. (2005). "Corporate social responsibility and stakeholder approach: A conceptual review." International Journal of Business Governance and Ethics, 1(4), 277-302.

51. Katz, D.and R.L. Khan (1978). The social psychology of organizations $\left(2^{\text {nd }}\right.$ ed). New York, Wiley \& Sons, 35-68.

52. Kogut, B. (1988). "Joint Ventures: Theoretical and empirical perspectives", Strategic Management Journal, 9, 319-332. 
53. Kostova, T. and K. Roth (2003). "Social capital in multinational corporations and a micro-macro model of its formation." Academy of Management Review. 28: 297-317.

54. Kumar, N., L.K. Scheer, and J. E. M. Steenkamp (1995), "The Effects of Perceived Interdependence on Dealer Attitudes," Journal of Marketing Research, 32:348-56.

55. Lewis, S. (2003). "Reputation and corporate social responsibility." Journal of Communication Management, 7(4): 356-364.

56. Lindskold, S. (1978), "Trust Development, the GRIT Proposal and the Effects of Conciliatory Acts on Conflict and Cooperation" Psychological Bulletin, 85(4), 772-93.

57. Maignan, I., B. Hillebrand, and D. McAlister (2002), "Managing Socially Responsible Buying: How to Integrate Non-economic Criteria into the Purchasing Process," European Management Journal, 20: 641648.

58. McCarter, M. W., Mahoney, J. T., \& Northcraft, G. B. (2011). "Testing the waters: Using collective real options to manage the social dilemma of strategic alliances." Academy of Management Review, 36: 621640.

59. McGuire, J. B., Sundgren, A., and Schneeweis, T. 1988. "Corporate social responsibility and firm financial performance." Academy of Management Journal, 31: 854-872.

60. Murphy, P.1 R. and R. F. Poist (2002), "Socially Responsible Logistics: An Exploratory Study," Transportation Journal, Vol. 41, No. 4, pp. 23-35.

61. Orlitzky, M. and J.D. Benjamin (2001). "Corporate social performance and firm risk: A meta-analytic review." Business and Society. 40: 369-398.

62. Palanski, M. E., \& Yammarino, F. J. (2009). "Integrity and leadership: A multi-level conceptual framework." Leadership Quarterly, 20: 405-420.

63. Pfeffer, J., \& Salancik, G. R. (1978). The external control of organizations: A resource dependence approach. NY: Harper and Row Publishers.

64. Podolny, J.M. (1993). “A status-based model of market competition.” American Journal of Sociology, 98, 829-872.

65. Portes, A. (1998). "Social Capital: Its origins and applications in modern sociology." Annual Review of Sociology, 24:1-24.

66. Powell, W.W. (1990). "Neither market nor hierarchy: Network forms of organization." In B.M. Staw and L.L. Cummings (eds). Research in Organizational Behavior, 12, 295-336.

67. Prahalad, C.K. and Hamel, G. (1994). "Strategy as a field of study: Why search for a new paradigm". Strategic Management Journal, 15:5-16.

68. Preston, L.E. and T. Donaldson (1999). "Stakeholder management and organizational wealth.” Academy of Management Review. 24: 619-621.

69. Ring, P.S. and A.H. Van de Ven. (1994). "Development process of cooperative interorganizational relations." Academy of Management Review. 19: 90-118.

70. Simms, J. (2002). "Business: Corporate Social Responsibility- You know it makes sense." Accountancy. 130: 1311.

71. Smeltzer, L.R. (1997). "The origin and meaning of trust in buyer-seller relationships." International Journal of Purchasing and Materials Management, 33(1), 40-49.

72. Teece, D.J. (1992), "Competition, cooperation and innovation: organizational arrangements for regimes of rapid technological progress", Journal of Economic Behavior and Organization, 18:1-25.

73. Verschoor, C.C. (2003). "More evidence of better financial performance." Strategic Finance. 5:18-20.

74. Waddock, S. (2003). "Myths and realities of social investing." Organization Science, 16, 3: 359.

75. Waddock, S.A. and Graves, S. (1997). "The corporate social performance link." Strategic Management Journal 18:303-317.

76. Walker, G., B. Kogut and W. Shan (1997). "Social capital, structural holes and the formation of an industry network." Organization Science, 8:109-125.

77. Williamson, O. (1991). "Comparative economic organization: The analysis of discrete structural alternatives.” Administrative Science Quarterly, 36:269-296.

78. Williamson, O.E. (1979), "Transaction cost economics: the governance of contractual relations", Journal of Law and Economics, 22:233-61.

79. Zaheer, A., B. McEvily and V. Perrone (1998). "The strategic value of buyer-seller relationships." International Journal of Purchasing and Materials Management, 34(3):20-27. 